\title{
高強度コンクリートを用いた実大柱部材の 材齢15年における強度性状および中性化 STRENGTH AND CARBONATION OF HIGH-STRENGTH CONCRETE IN FULL-SCALE COLUMNS AT THE AGE OF 15 YEARS
}

\author{
杉山 央*, 栘田佳寛**, 阿部道彦***, 安田正雪**** \\ Hisashi SUGIYAMA, Yoshihiro MASUDA, Michihiko ABE \\ and Masayuki YASUDA
}

\begin{abstract}
This paper describes a study on the long-term strength development and carbonation of high-strength concrete in full-scale models. Four types of full-scale columns were made of two high-strength concretes, which design strength were 60 and $100 \mathrm{~N} / \mathrm{mm}^{2}$ (Fc60 and Fc100), respectively. Core specimens were drilled out of the columns at the age of 15 years. The compressive strength and carbonation depth of the core specimens were tested. As a result, the increase of strength from 91 days to 15 years was clearly recognized in both Fc60 and Fc100 concretes. The strength of core specimens taken from the center of the column was higher than that of core specimens taken from the corner of the column. The carbonation depth at 15 years is $0 \mathrm{~mm}$, in both $\mathrm{Fc} 60$ and $\mathrm{Fc} 100$ concretes. However, the consumption of $\mathrm{Ca}(\mathrm{OH}) 2$ and production of $\mathrm{CaCO}_{3}$ were revealed by XRD analysis. $\mathrm{C}_{3} \mathrm{~S}$ and $\mathrm{C}_{2} \mathrm{~S}$ still remained in both $\mathrm{Fc} 60$ and $\mathrm{Fc} 100$ concretes at 15 years.
\end{abstract}

Keywords: High-strength concrete, Full-scale experiment, Core specimen, Long-term strength development, Carbonation, X-ray diffraction analysis 高強度コンクリート，実大実験，コア供試体，長期強度発現，中性化，X 線回折

\section{1. はじめに}

鉄筋コンクリート造建築物の高層化を図るため、近年、建築工事 において高強度コンクリートが広く使用されている。建築分野にお ける高強度コンクリートは、1980年代に大手建設会社が高層鉄筋コ ンクリート造集合住宅の設計・施工法を競って開発した時の要素技 術として研究開発が進められた。当初はスランプが $15 \mathrm{~cm}$ 前後のコ ンクリートであったが、やがて流動化剂や高強度用高減水性混和剂 （現在の高性能AE減水剂）の開発により、スランプが $21 \mathrm{~cm}$ 程度の 軟練りコンクリートが使用されるようになった。1988年から5箇年に わたって実施された建設省総合技術開発プロジェクト「鉄筋コンク リート造建築物の超軽量・超高層化技術の開発 ${ }^{1)} 」 （$ 略称：「総プロ New RC」) では、設計基準強度 $600 \mathrm{kgf} / \mathrm{cm}^{2}\left(60 \mathrm{~N} / \mathrm{mm}^{2}\right)$ でスラン プが21〜25cmの高強度コンクリートを対象として、使用するセメ ント・骨材・混和材料の品質基準およびそれらの材料を用いたコン クリートの調合方法・施工方法・品質管理基準が作成された。さら に、設計基準強度 $600 \mathrm{kgf} / \mathrm{cm}^{2}$ を超えるコンクリートを開発するため のコンクリート用材料の開発、品質評価方法、調合方法および施工 方法についても検討が進められた。その研究成果はJIS、学協会の 仕様書、指針等に幅広く有効活用され2)、今日の高強度コンクリー トの技術の普及に大きく寄与した。

このように建築工事に用いられる高強度コンクリートは近年急速
に普及した材料であるが、その歴史は比較的浅く、長期的な性状に ついては明らかにされていない。総プロNew RCから15年を迎えた が、本研究は当時作製され、以後は屋外で暴露されている実大試験 体を調査することにより、高強度コンクリートの長期性状を明らか にすることを目的とした。総プロNew RCでは高強度コンクリート を用いた実大施工実験が計画され、設計基準強度 $600 \mathrm{kgf} / \mathrm{cm}^{2}$ のコン

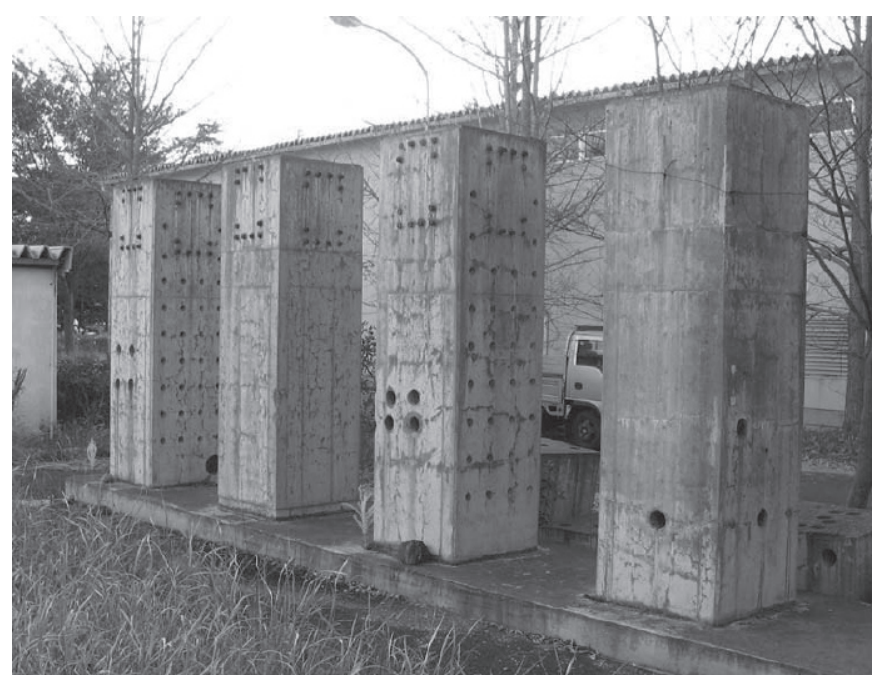

写真1 柱試験体の外観（右からNo.2，No.3，No.4，No.5）

\footnotetext{
* 国土交通省国土技術政策総合研究所住宅生産研究室 室長・工博

** 㨍都宮大学工学研究科地球環境デザイン学専攻 教授. 工博

*** 工学院大学工学部建築学科 教授.工博

**** 東洋建設株美浦研究所材料研究室 主任研究員
}

Director, Housing Production Division, National Institute for Land Infrastructure and Management, Ministry of Land, Infrastructure and Transport, Dr. Eng.

Prof., Dept. of Architecture, Utsunomiya Univ., Dr. Eng.

Prof., Dept. of Architecture, Faculty of Engineering, Kogakuin Univ., Dr. Eng. Senior Researcher, Technical Research Institute, Miho, Toyo Construction 
クリートを用いたラーメン架構（2層）の施工実験、ならびに設計 基準強度 $1000 \mathrm{kgf} / \mathrm{cm}^{2}\left(100 \mathrm{~N} / \mathrm{mm}^{2}\right)$ および $600 \mathrm{kgf} / \mathrm{cm}^{2}$ のコンクリー 卜を用いた実大柱部材の施工実験が行われた ${ }^{3)}$ 。本研究では後者の 実大柱部材試験体（以降、柱試験体）を対象とし、材齢 15 年にお けるコア強度および中性化深さを調査した。また、柱試験体からコ ンクリート試料を採取してX線回折法により組成分析を行った。本 研究の成果は、高強度コンクリートの長期的な性状を明らかにする ための重要な基礎資料となり、今後高強度コンクリートの適切かつ 合理的な調合設計・製造方法を確立することに活用されることが期 待される。

写真1に研究対象である高強度コンクリートを用いた柱試験体を 示す。なお、総プロNew RC実施当時は重力単位が用いられていた が、その後国際単位系であるSI単位へ移行したため、本研究ではSI 単位に従って強度等を表記することとする。

\section{2. 実験概要}

\section{1 柱試験体の概要}

(1) コンクリートの使用材料および調合： 使用材料の種類および
リートの調合およびフレッシュ性状の試験結果を表 2 に示す。コンク リートの製造は、容量 $3.0 \mathrm{~m}^{3}$ の強制二軸ミキサを備えたレディーミ クストコンクリート工場で行った ${ }^{4)}$ 。 F c60 は結合材として普通ポル

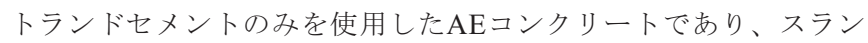
プ21〜25 cm、空気量3\%、材齢91日で設計基準強度 $60 \mathrm{~N} / \mathrm{mm}^{2}$ をそれ ぞれ満足するように調合を定めた5), 6) F F 100は結合材として普通ポ ルトランドセメントとシリカフュームを質量比で $9: 1$ に混合して使 用したnon-AEコンクリートであり、空気量 $2 \%$ 以下、材齢91日で設 計基準強度 $100 \mathrm{~N} / \mathrm{mm}^{2}$ をそれぞれ満足するように調合を定めた5), 6)。 スランプは $25 \mathrm{~cm}$ 目標としていたが、先行して練混ぜたFc100-Aの

表1 使用材料の種類および物性値

\begin{tabular}{|c|c|}
\hline セメント & 普通ポルトランドセメント (密度 $\left.: 3.16 \mathrm{~g} / \mathrm{cm}^{3}\right)$ \\
\hline 混和材 & シリカフューム(比表面積: $200000 \mathrm{~cm}^{2} / \mathrm{g}$ ，密度 $: 2.20 \mathrm{~g} / \mathrm{cm}^{3}$ ) \\
\hline 細骨材 & $\begin{array}{l}\text { (1)鹿島産陸砂 (表乾密度: } 2.62 \mathrm{~g} / \mathrm{cm}^{3}, \text { 吸水率: } 1.25 \%, F M: 2.65 \text { ) } \\
\text { (2)葛生産石灰碎砂(表乾密度: } 2.69 \mathrm{~g} / \mathrm{cm}^{3}, \text { 吸水率:1.66\%,FM:2. 59) } \\
\text { ※細骨材は(1)と(2)を質量比7:3の割合で混合して使用した。 }\end{array}$ \\
\hline 粗骨材 & $\begin{array}{l}\text { 岩瀬産砕石 (表乾密度: } 2.66 \mathrm{~g} / \mathrm{cm}^{3} \text {, 吸水率: } 0.59 \%, F M: 6.71 \text {, 実積率: } \\
61.1 \% \text { ) }\end{array}$ \\
\hline $\begin{array}{l}\text { 化 学 } \\
\text { 混和剂 }\end{array}$ & $\begin{array}{l}\text { (Fc100用) アミノスルホン酸系高強度用高減水性混和剤 } \\
\text { (Fc60用) ポリカルボン酸系高強度用高減水性混和剂 }\end{array}$ \\
\hline
\end{tabular}
物性值を表 1 に示す。な お、表1中の高強度用高 減水性混和剂は柱試験体 作製当時の呼称であり、 今日の高性能AE減水剤 と同じである。コンク

表2 コンクリートの調合およびフレッシュ性状の試験結果

\begin{tabular}{|c|c|c|c|c|c|c|c|c|c|c|c|c|}
\hline \multirow{3}{*}{$\begin{array}{c}\text { コンクリート } \\
\text { 記号 }\end{array}$} & \multicolumn{8}{|c|}{ 調合 } & \multicolumn{4}{|c|}{ フレッシュ性状の試験結果（荷卸時） } \\
\hline & \multirow{2}{*}{$\begin{array}{c}\text { 水結合材比 } \\
(\%)\end{array}$} & \multirow{2}{*}{$\begin{array}{c}\text { 細骨材率 } \\
(\%)\end{array}$} & \multicolumn{6}{|c|}{ 単位量 $\left(\mathrm{kg} / \mathrm{m}^{3}\right)$} & \multirow{2}{*}{$\begin{array}{r}\text { スランプ } \\
(\mathrm{cm})\end{array}$} & \multirow{2}{*}{$\begin{array}{c}\text { スランプ フロ } \\
(\mathrm{mm})\end{array}$} & \multirow{2}{*}{$\begin{array}{c}\text { 空気量 } \\
(\%)\end{array}$} & \multirow{2}{*}{$\begin{array}{c}\text { コンクリート } \\
\text { 温度 }\left({ }^{\circ} \mathrm{C}\right)\end{array}$} \\
\hline & & & 水 & セメト & 沙かフューム & 細骨材 & 粗骨材 & 混和剂 ※ & & & & \\
\hline Fc100-A & 20.0 & 39.6 & 160 & 720 & 80 & 531 & 910 & $\mathrm{C} \times 1.7 \%$ & 23.0 & $436 \times 436$ & 1.3 & 26.0 \\
\hline Fc100-B & 20.0 & 39.6 & 160 & 720 & 80 & 531 & 910 & $\mathrm{C} \times 2.0 \%$ & 25.9 & $608 \times 598$ & 1.0 & 27.0 \\
\hline Fc60 & 27.0 & 44.1 & 165 & 611 & - & 713 & 910 & $c \times 1.9 \%$ & 25.4 & $675 \times 620$ & 3.7 & 26.0 \\
\hline
\end{tabular}

※ アミノスルホン酸系高強度用高減水性混和剤( Fc100用)、ポリカルボン酸系高強度用高減水性混和剤 ( F c 60用)
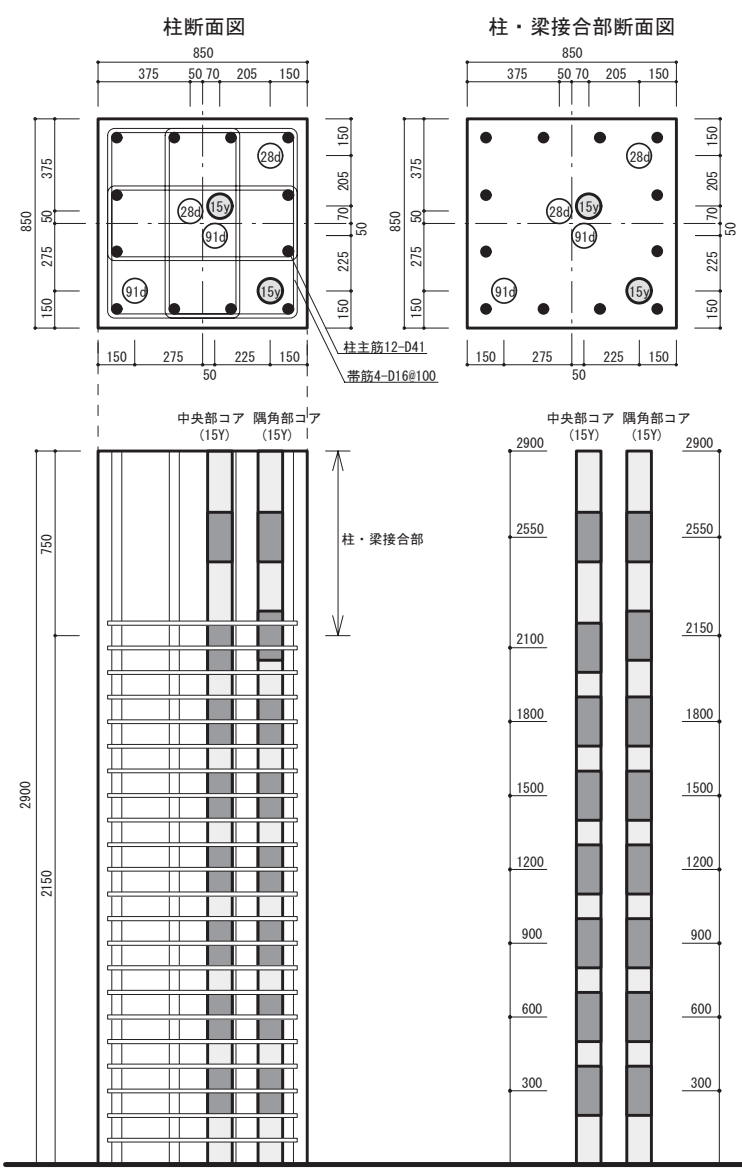

図1 柱試験体No. 2の形状・法・コア採取位置

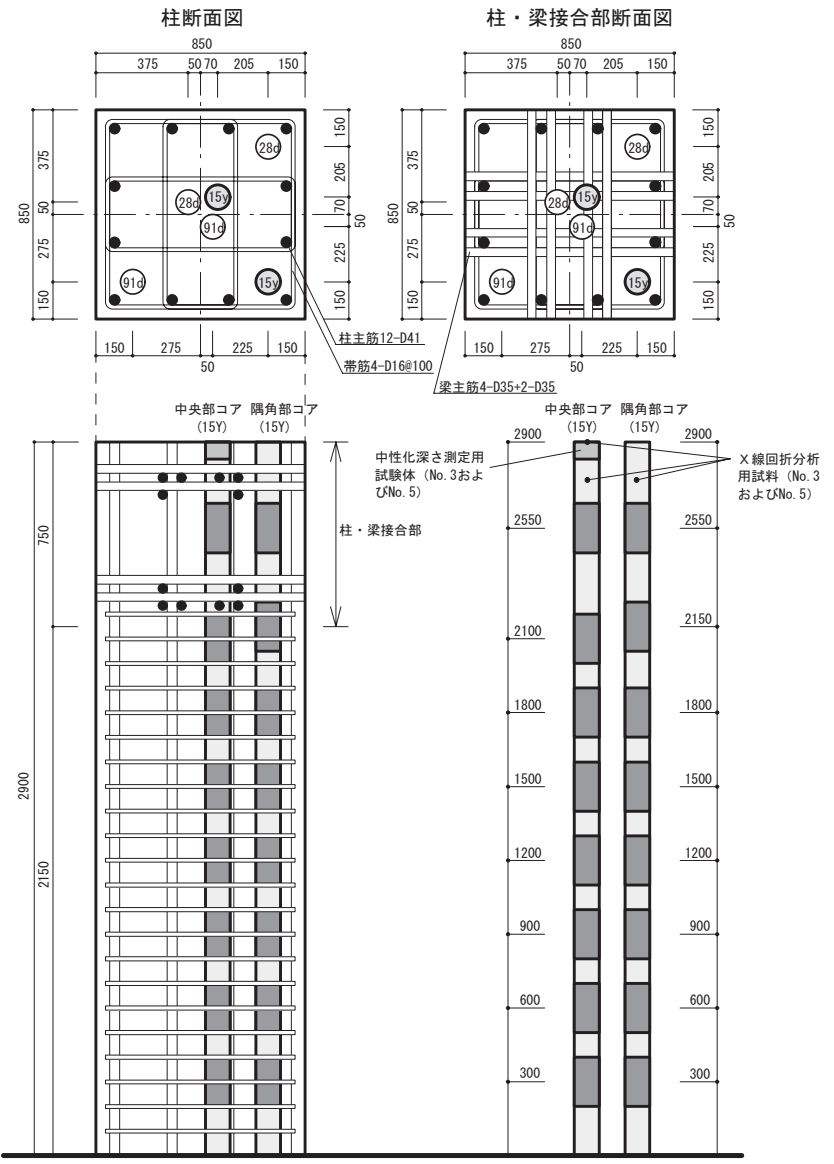

図2 柱試験体No. 3、No.4およびNo. 5の形状・法・コア採取位置 
表3 柱試験体の作製条件

\begin{tabular}{|c|c|c|c|c|}
\hline 試験体 & $\begin{array}{c}\text { コンクリート } \\
\text { 調合 }\end{array}$ & 型枠の種類 & 打込み方法 & 養生方法 \\
\hline 柱NNo. 2 & Fc100-A & 合板型枠 & VH分離打与 & \multirow{4}{*}{$\begin{array}{l}\text { 材齢1日で脱型、その後、養生を } \\
\text { 6間シート掛 } \\
\text { 実施した。 }\end{array}$} \\
\hline 柱NNo. 3 & Fc100-B & 合板型枠 & 一体打ち & \\
\hline 柱NNo. 4 & $\mathrm{Fc} 60$ & 鋼製型枠 & 一体打ち & \\
\hline 柱NNo. 5 & Fc60 & 合板型枠 & 一体打ち & \\
\hline
\end{tabular}

スランプが目標值より小さかったため、Fc100-Bでは化学混和剤の 添加量を増やして目標值を満足するようにした。コンクリートの製 造から型枠への打込みまでに要した時間は30４0分であった ${ }^{4)}$ 。 お、表2に示したフレッシュ性状の試験結果は荷卸時における試験 結果である。

(2) 柱試験体の種類： 柱試験体の形状・寸法を図 1 および図2に 示す。また、柱試験体の作製条件を表3に示す3), 4)。柱No.2および 柱No.3は設計基準強度を $100 \mathrm{~N} / \mathrm{mm}^{2}$ としており、柱No.2では調合 Fc100-Aのコンクリートを、柱No.3では調合Fc100-Bのコンクリー トをそれぞれ使用した。柱No.2および柱No.3に共通して、型枠に は合板（厚さ $12 \mathrm{~mm}$ ）を使用した。柱No.4および柱No.5は設計基準 強度を $60 \mathrm{~N} / \mathrm{mm}^{2}$ としており、柱No.4では鋼製型枠（厚さ $3.2 \mathrm{~mm}$ ） 柱No.5では合板型枠を使用した。なお、当初は柱No.1（設計基準 強度 $100 \mathrm{~N} / \mathrm{mm}^{2}$ 、調合 $\mathrm{Fc} 100-\mathrm{A}$ 、鋼製型枠使用、VH分離打ち）も作 製したが、材齢15年を迎える以前に解体している。

(3)コンクリートの打込みおよび養生： コンクリートの打込みは 1991年10月8日に実施された。場所は茨城県つくば市の建設省建築 研究所（現在は独立行政法人建築研究所）内の実験場である。表3 における打込み方法のうち、VH分離打ちとは梁下までシュートを用 いてコンクリートを打ち込んだ後、柱・梁接合部の梁筋を落とし込 み、再度梁筋の上からコンクリートを打ち込む方法である。ただ し、実際には柱・梁接合部の梁筋は設置しなかった。また、一体 打ちとは、梁筋が最初から設置してある型枠内に連続してコンク リートを打ち込む方法である゙”。コンクリートの打込みは最大吐出 量 $65 \mathrm{~m}^{3} / \mathrm{h}$ のブーム式ポンプ車（ブーム実長 $22.4 \mathrm{~m} ）$ を用い、VH分離 打ちでは圧送管先端のフレキシブルホースを型枠の最下部まで挿入 し、コンクリートの天端上昇にともなってホースを引き上げ、梁 下すなわち図1における柱・梁 接合部の下端までコンクリー 卜を打ち込んだ。その4時間 20 分経過後、柱・梁接合部のコ ンクリートを打ち込んだ。ま た、一体打ちでは梁筋の上部 からコンクリートを落とし込 み、柱試験体の天端までコン クリートを連続して打ち上げ た。コンクリートの打込み速 度は $25 \mathrm{~m}^{3} / \mathrm{h}$ とした ${ }^{4)}$ 。材齢 1 日 に脱型し、材齢7日までビニー ルシートで柱試験体全面を 覆って養生した。これ以降は 写真1に見られるように日射や 雨がかり等を防ぐものは設置 せず、屋外に暴露した。表4に

※気象庁統計データによる。
試験体作製から材齢15年の試験までの気象条件を示す。日平均気 温の年平均値は、東京に比べて $2 \sim 3{ }^{\circ} \mathrm{C}$ 低い環境である。また、柱 試験体と同じコンクリートを用いて標準養生円柱供試体（ $\phi 100 \times$ 200mm）を作製した。

\section{2 実験方法}

(1)コア採取および圧縮強度試験： 図1および図2に柱試験体から のコア採取位置を示す。1つの柱試験体につき中央部および隅角部 の 2 箇所から鉛直方向に高さ $2900 \mathrm{~mm}$ のコアを採取した。採取した コアは、所定の高さ位置で長さ $200 \mathrm{~mm} に$ 切断・研磨し、圧縮強度 試験に供した。試験材齢は28日、91日および15年である。材齢 28 日および91日の試験結果については、すでに山浦らにより報告さ れている7)。材齢 15 年については、2007年6月28日にコアの採取、 切断および研磨を行い、翌日に圧縮強度試験を実施した。正確には 材齢15年8 8 月である。標準養生円柱供試体については、材齡28日 および91日に圧縮強度試験を実施している。

（2）中性化深さ試験： 材齢 15 年において、柱No.3および柱No.5の 図2に示す位置より中性化深さ試験に用いるコア試験体を採取し、 円柱の中心軸と平行方向に割裂させた。割裂面にフェノールフタレ イン $1 \%$ 溶液を噴霧した後、JIS A 1152 「コンクリートの中性化深さ の測定方法」に従って中性化深さを測定した。

(3) X 線回折分析： 材齢 15 年において、図2に示すように柱No.3 および柱No.5の中央部、隅角部および表面部（中性化深さ測定用 試験体の上面部）からコンクリート小片を採取し、ハンマーを用

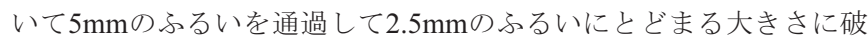
砕した。水和反応を停止させるため、アセトンに約24時間浸した 後、真空凍結乾燥器を用いて、温度 $-50^{\circ} \mathrm{C}$ 、真空度 $7.0 \mathrm{~Pa}$ 以下の条 件で3日間乾燥させた。続いて、乾燥終了後の小片に内部標準物質 として酸化マグネシウム（MgO）を内割りで $20 \mathrm{mass} \%$ 加え、遊星 型ボールミルを用いて微粉砕し、X線回折分析用の試料とした。 $\mathrm{X}$ 線回折分析における測定条件は、ターゲット: $\mathrm{Cu}$ 、管電圧 : $40 \mathrm{kV}$ 、管電流 : $20 \mathrm{~mA}$ 、測定範囲 : $2 \theta=5 \sim 70 \mathrm{deg}$ 、ステップ角度 : $0.02 \mathrm{deg}$ 、計数時間：1秒である。

表4 茨城県つくば市の気象条件

\begin{tabular}{|c|c|c|c|c|c|c|c|c|c|}
\hline 年 & $\begin{array}{l}\text { 日平均気温の } \\
\text { 年平均値 }\left({ }^{\circ} \mathrm{C}\right)\end{array}$ & $\begin{array}{l}\text { 日最高気温の } \\
\text { 年平均値 }\left({ }^{\circ} \mathrm{C}\right)\end{array}$ & $\begin{array}{l}\text { 日最低気温の } \\
\text { 年平均値 }\left({ }^{\circ} \mathrm{C}\right)\end{array}$ & $\begin{array}{c}\text { 最高気温 } \\
\left({ }^{\circ} \mathrm{C}\right)\end{array}$ & $\begin{array}{c}\text { 最低気温 } \\
\left({ }^{\circ} \mathrm{C}\right)\end{array}$ & $\begin{array}{c}\text { 湿度の } \\
\text { 年平均値 } \\
(\%)\end{array}$ & 降水量 (mm) & $\begin{array}{c}\text { 日照時間 } \\
\text { (h) }\end{array}$ & 降雪 $(\mathrm{cm})$ \\
\hline 1991 & 14.1 & 19.1 & 9.3 & 36.8 & -8.5 & 75.0 & 1841.0 & 1804.1 & 1 \\
\hline 1992 & 13.6 & 18.9 & 8.6 & 36.9 & -7.1 & 76.0 & 1282.0 & 1909.1 & 18 \\
\hline 1993 & 13.1 & 18.2 & 8.3 & 33.2 & -7.3 & 77.0 & 1380.5 & 1725.7 & 0 \\
\hline 1994 & 14.4 & 19.9 & 9.4 & 37.0 & -8.7 & 75.0 & 1050.5 & 2130.9 & 38 \\
\hline 1995 & 13.7 & 19.2 & 8.6 & 36.0 & -8.3 & 74.0 & 1159.5 & 2070.7 & 1 \\
\hline 1996 & 13.2 & 18.7 & 8.0 & 37.8 & -8.4 & 75.0 & 1082.5 & 2092.8 & 28 \\
\hline 1997 & 14.2 & 19.7 & 9.0 & 35.9 & -7.5 & 76.0 & 1002.5 & 2184.7 & 2 \\
\hline 1998 & 14.3 & 19.4 & 9.7 & 35.9 & -7.1 & 81.0 & 1523.0 & 1568.5 & 32 \\
\hline 1999 & 14.6 & 20.2 & 9.4 & 35.0 & -8.1 & 73.0 & 1164.5 & 2077.0 & 2 \\
\hline 2000 & 14.4 & 19.9 & 9.4 & 35.7 & -7.6 & 70.0 & 1382.0 & 2079.0 & 6 \\
\hline 2001 & 13.8 & 19.5 & 8.6 & 36.6 & -9.4 & 69.0 & 1220.5 & 2100.6 & 28 \\
\hline 2002 & 14.2 & 19.6 & 9.1 & 35.9 & -6.9 & 72.0 & 1069.5 & 2062.3 & 0 \\
\hline 2003 & 13.6 & 18.7 & 8.9 & 33.8 & -8.6 & 75.0 & 1385.5 & 1762.5 & 10 \\
\hline 2004 & 14.8 & 20.4 & 9.5 & 37.3 & -7.0 & 74.0 & 1606.5 & 2232.5 & 7 \\
\hline 2005 & 13.7 & 19.2 & 8.6 & 34.4 & -7.4 & 74.0 & 1132.0 & 2067.9 & 27 \\
\hline 2006 & 14.2 & 19.0 & 9.6 & 34.6 & -7.5 & 77.0 & 1616.5 & 1672.1 & 26 \\
\hline 2007 & 15.4 & 20.7 & 10.5 & 37.7 & -5.3 & 75.0 & 1085.5 & 1980.8 & 0 \\
\hline
\end{tabular}

※1991年10月に柱試験体作製。2007年6月に村齢15年コア採取。 


\section{3. 実験結果および考察}

表5にコア供試体の圧縮強度試験結果を示す。なお、本研究では 材齢 15 年における高強度コンクリートの強度性状を主対象として いるが、表5には既発表7)である材齢28日および91日の試験結果も 示した。以降では、これらも含めて考察を行う。材齢91日では柱 No.2中央部および柱No.3隅角部で設計基準強度に到達していない コア供試体も見られたが、コア平均強度はそれぞれの柱試験体で設 計基準強度を満足した。材齢 15 年ではすべてのコア供試体が設計 基準強度を満足した。

\section{1 実大柱部材の垂直方向における強度分布}

図3にコア供試体の採取高さと強度の関係を示す。毛見 ${ }^{8)}$ 、 Kasai ら 9)の研究報告に代表されるように、一般的に $40 \mathrm{~N} / \mathrm{mm}^{2}$ 以下の 強度レベルのコンクリートでは圧密や密度の高い材料（セメントや 骨材）の沈降による影響により、上部よりも下部に位置するコンク リートの方が強度が高くなることが知られている。しかし、梅本 $ら^{10)}$ の実験結果からもわかるように、60N/ $\mathrm{mm}^{2}$ を超える高強度コン クリートでは粘性が高いため、材料の密度の違いによる沈降なども 少なく、垂直方向における強度差は $40 \mathrm{~N} / \mathrm{mm}^{2}$ 以下のコンクリートよ りも小さくなることが考えられる。
本研究では、Fc60N/mm 級の柱No.4および柱No.5の中央部にお ける材齢 15 年のコア供試体強度は、上部よりも下部の方が高い傾 向が認められた。材龄91日においても同様の傾向が認められてい る7)。これに関連して、下川ら ${ }^{11}$ は本研究で対象としている柱試験 体に混入した気泡の量を調查しており、特に柱No.5では高さ位置 によって気泡量のバラツキが大きいことを報告している。高強度コ ンクリートは粘性が高いため、打ち込み時に混入した気泡が抜けに くくなる。このため、棒形振動機の挿入位置あるいは加振時間に よってコンクリート中における気泡の分布にバラツキが生じ、コア 供試体強度に影響を及ぼしたことも推察できる。

一方、Fc100N/mm²級の柱No.2および柱No.3の材齢28日、91日 および 15 年におけるコア供試体強度は高さ位置によって差がある が、コア供試体の採取高さと強度には明確な関係が認められなかっ た

\section{2 実大柱部材の部位による強度性状}

図4に部位別（中央部および隅角部）によるコア供試体強度の関 係を示す。高強度コンクリートは単位セメント量が多く、しかも柱 のような断面厚の大きなコンクリート部材に用いた場合は、セメン トの水和熱が部材内部に蓄積されることにより温度上昇が生じ、高

表5 コア供試体の圧縮強度試験結果

(単位 : $\mathrm{N} / \mathrm{mm}^{2}$ )

\begin{tabular}{|c|c|c|c|c|c|c|c|c|c|c|c|c|c|c|c|c|c|c|c|c|c|c|c|c|}
\hline 材齢 & \multicolumn{8}{|c|}{ 28日 } & \multicolumn{8}{|c|}{ 91日 } & \multicolumn{8}{|c|}{ 15年 } \\
\hline 試験体 & \multicolumn{2}{|c|}{ 柱№. 2} & \multicolumn{2}{|c|}{ 柱NNo. 3} & \multicolumn{2}{|c|}{ 柱NNo. 4} & \multicolumn{2}{|c|}{ 柱NNo. 5} & \multicolumn{2}{|c|}{ 柱NNo. 2} & \multicolumn{2}{|c|}{ 柱NNo. 3} & \multicolumn{2}{|c|}{ 柱NNo. 4} & \multicolumn{2}{|c|}{ 柱№. 5} & \multicolumn{2}{|c|}{ 柱NNo. 2} & \multicolumn{2}{|c|}{ 柱№. 3} & \multicolumn{2}{|c|}{ 柱NNo. 4} & \multicolumn{2}{|c|}{ 柱№. 5} \\
\hline 高さ (mm) & 中央 & 隅角 & 中央 & 隅角 & 中央 & 隅角 & 中央 & 隅角 & 中央 & 隅角 & 中央 & 隅角 & 中央 & 隅角 & 中央 & 隅角 & 中央 & 隅角 & 中央 & 隅角 & 中央 & 隅角 & 中央 & 隅角 \\
\hline 300 & \begin{tabular}{|l|l}
110.8 \\
\end{tabular} & 92.7 & 118.2 & 98.0 & 78.3 & 80.0 & 73.9 & 75.9 & 96.6 & $\overline{110.3}$ & 114.0 & 97.7 & 84.7 & 83.8 & 91.8 & 87.5 & 137.6 & 128.8 & 146.2 & 139.2 & 129.7 & 1115.7 & 132.4 & $\overline{107.0}$ \\
\hline 600 & - & - & - & - & - & - & - & - & - & - & - & - & - & - & - & - & 143.6 & 132.7 & 146.6 & 130.5 & 125.6 & 114.7 & 134.7 & 119.6 \\
\hline 900 & 105.9 & 75.3 & 114.4 & 90.2 & 79.9 & 80.7 & 61.5 & 74.4 & 104.1 & 110.4 & 107.2 & 111.5 & 86.4 & 73.6 & 84.7 & 85.9 & 141.4 & 129.6 & 137.2 & 130.6 & 121.1 & 116.5 & 125.6 & 107.8 \\
\hline 1200 & - & - & - & - & - & - & - & - & - & - & - & - & - & - & - & - & 135.2 & 122.2 & 131.2 & 137.9 & 116.7 & 126.9 & 130.4 & 111.6 \\
\hline 1500 & 114.8 & 110.9 & 78.0 & 111.1 & 61.6 & 78.3 & 72.2 & 76.4 & 113.3 & 113.8 & 114.5 & 88.1 & 81.1 & 82.9 & 81.0 & 73.9 & 132.3 & 126.7 & 134.2 & 131.8 & 121.6 & 123.5 & 126.4 & 123.6 \\
\hline 1800 & - & - & - & - & - & - & - & - & - & - & - & - & - & - & - & - & 132.3 & 121.5 & 140.9 & 134.8 & 115.1 & 110.4 & 115.1 & 110.2 \\
\hline 2550 & 115.4 & 113.0 & 114.5 & 102.7 & 67.5 & 68.8 & 66.5 & 69.8 & 105.1 & 103.8 & 106.7 & 95.7 & 80.3 & 79.9 & 72.2 & 87.4 & 135.8 & 148.8 & 150.3 & 131.1 & 110.2 & 110.5 & 110.9 & 114.1 \\
\hline 平均 & 111.7 & 99.4 & 106.3 & 97.6 & 71.8 & 76.6 & 68.6 & 73.2 & 104.8 & 109.2 & 110.6 & 100.6 & 83.1 & 78.9 & 82.4 & 83.6 & 136.7 & 131.4 & 141.3 & 133.3 & 118.8 & 117.7 & 123.0 & 113.2 \\
\hline 標準偏差 & 3.8 & 14.0 & 16.4 & 8.9 & 7.6 & 4.3 & 4.9 & 2.9 & 5.9 & 3.3 & 3.6 & 8.8 & 2.5 & 4.3 & 7.1 & 5.1 & 3.8 & 8.7 & 6.2 & 3.3 & 6.5 & 5.9 & 9.4 & 5.4 \\
\hline 変動係数 (\%) & 3.4 & 14.1 & 15.4 & 9.2 & 10.5 & 5.6 & 7.1 & 4.0 & 5.6 & 3.1 & 3.3 & 8.8 & 3.0 & 5.4 & 8.6 & 6.1 & 2.8 & 6.6 & 4.4 & 2.5 & 5.5 & 5.0 & 7.7 & 4.8 \\
\hline コア平均 & \multicolumn{2}{|c|}{105.5} & \multicolumn{2}{|c|}{101.9} & \multicolumn{2}{|c|}{74.2} & \multicolumn{2}{|c|}{70.9} & \multicolumn{2}{|c|}{107.0} & \multicolumn{2}{|c|}{105.6} & \multicolumn{2}{|c|}{81.0} & \multicolumn{2}{|c|}{83.0} & \multicolumn{2}{|c|}{134.0} & \multicolumn{2}{|c|}{137.3} & \multicolumn{2}{|c|}{118.3} & \multicolumn{2}{|c|}{118.1} \\
\hline 標準養生供試体 & \multicolumn{2}{|c|}{117.9} & \multicolumn{2}{|c|}{122.9} & & & & & 12 & & 136 & & & & & & & - & 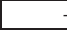 & - & & & & \\
\hline
\end{tabular}

※中央部では、柱・梁接合部の鉄筋を避けるため、高さ $2100 \mathrm{~mm}$ の位置よりコア供試体を採取した。
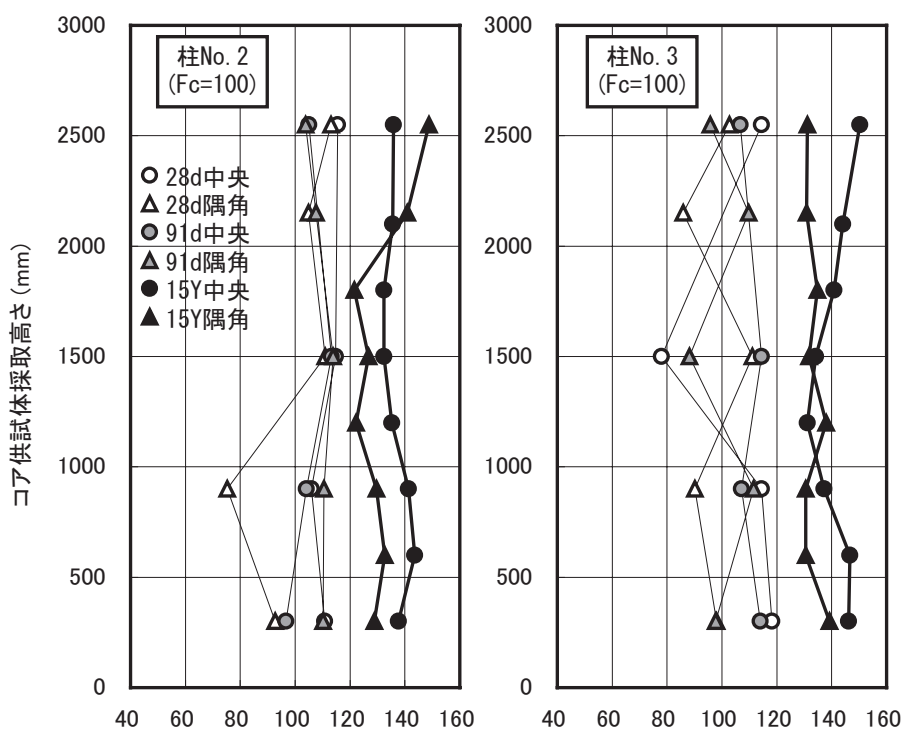

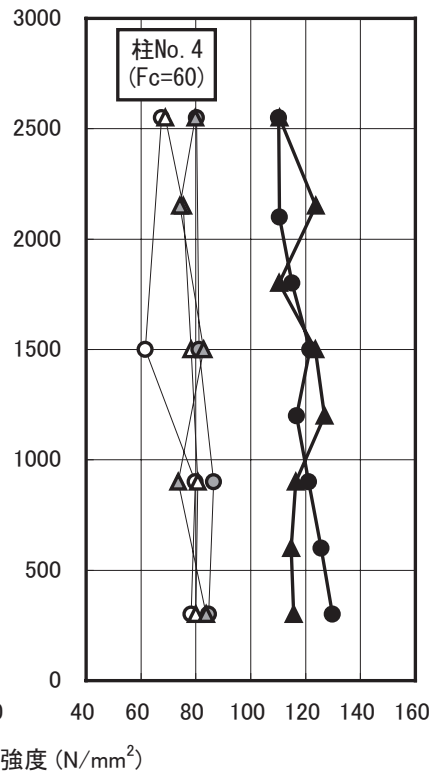

コア供試体強度 $\left(\mathrm{N} / \mathrm{mm}^{2}\right)$

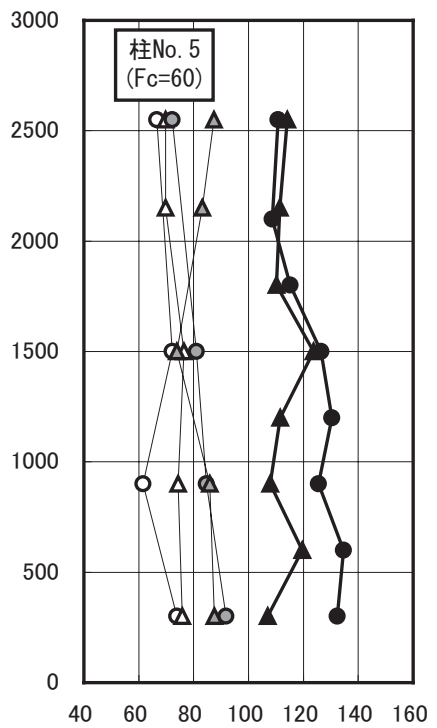

図3 コア供試体の採取高さと強度の関係 


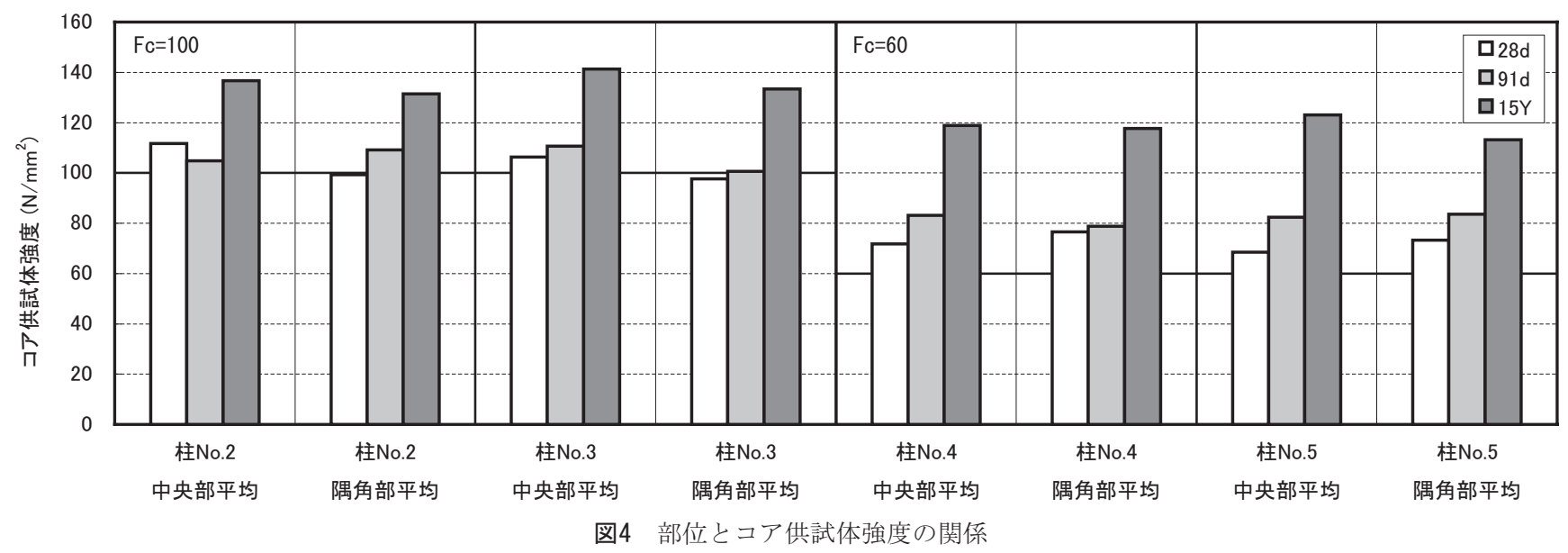

温状態となる。この初期材齢での高温履歴は、コンクリートの強度

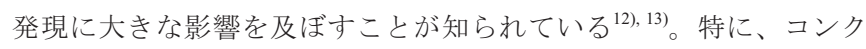
リート部材が履歴した最高温度が高いほど長期的な強度増進が停滞 することが報告されている ${ }^{14), 15), 16) 。 ~}$

本研究で対象とした柱試験体の打込夕後の温度履歴を計測した報 告 ${ }^{17}$ によれば、F $60 \mathrm{~N} / \mathrm{mm}^{2}$ 級の柱No.4の中央部における最高温度は $70.0^{\circ} \mathrm{C}$ 、柱No.5の中央部における最高温度は $72.7^{\circ} \mathrm{C}$ 、柱No. 5 の隅角 部における最高温度は約 $54^{\circ} \mathrm{C}$ であった。柱No.4および柱No.5につ いては、材齢28日で隅角部の方が中央部よりも高い強度を示した が、材齢15年では中央部の方が隅角部よりも高い強度を示した。

一方、Fc100 N/mm 級の柱No.2の中央部における最高温度は $76.6^{\circ} \mathrm{C}$ 、柱No.3の中央部における最高温度は $74.5^{\circ} \mathrm{C}$ 、柱No.3の隅角 部における最高温度は約 $55^{\circ}$ Cであった ${ }^{17)}$ 。柱No.2および柱No.3につ いては、材齢28日、91日および15年において中央部の方が隅角部 よりも高いコア強度を示す傾向が認められた。

すべての柱試験体に共通して、隅角部よりも高い最高温度を履歴 した中央部の方が、材齢 15 年では高いコア強度を示す結果となっ た。これは、隅角部と中央部の水分条件の違いに起因したものと考 えられる。すなわち、柱試験体を覆っていたビニールシートを材 齢7日で撤去した後は、柱試験体表面より水分の蒸発が進行するた め、表面に近い隅角部の方が中央部よりも含水率が低い状態とな る。加えて、降雨の場合、材齢28日および91日にコア採取した後 の残穴に雨水が溜まるため、この水分が残穴に近接した材齢 15 年 の中央部コア採取部分に供給されたことも考えられる。このように

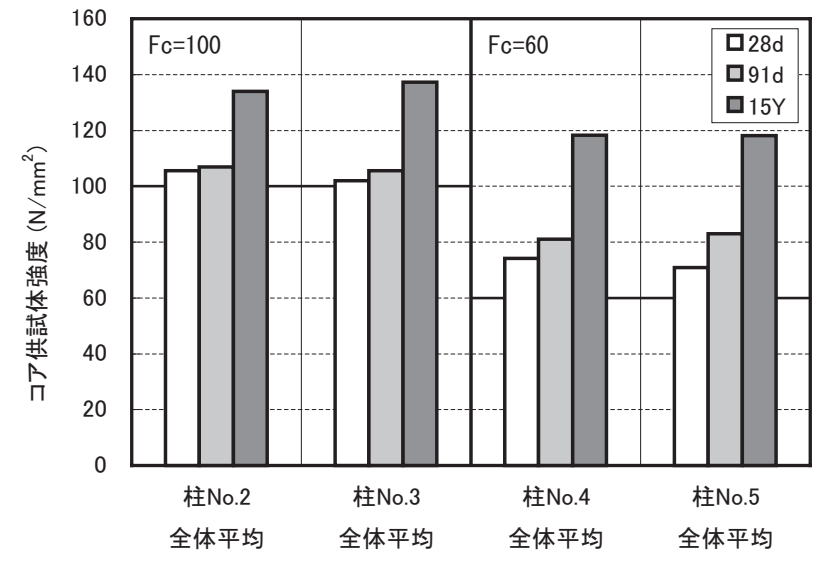

図5 柱試験体の平均コア供試体強度
柱試験体の中央部の方が隅角部よりも含水率が高い状態が長期間維 持されることにより、セメントの水和反応が円滑に進行し、より高 い長期強度を示したものと推察される。

\section{3 実大柱部材の平均強度}

図5に柱試験体の平均コア供試体強度を示寸。また、図6に材齢 91 日コア供試体強度に対する強度比を示す。

Fc60N/mm 級の柱No.4および柱No.5では、材齢91日以降も継続し て強度が増進したことがわかる。材齢 91 日から 15 年までの強度増 加は、柱No.4では37.3N $/ \mathrm{mm}^{2} 、$ 柱No.5では35.1N/mm゙ であった。ま た、材齢 15 年コア強度の 91 日コア強度に対する比は、柱No.4では 1.46、柱No.5では1.42であった。嵩ら ${ }^{18}$ は強度レベル $30 \sim 40 \mathrm{~N} / \mathrm{mm}^{2}$ （水セメント比 $57 \%$ ）の実大壁試験体の材齢 28 日から 25 年までの コア強度を調べているが、その調査結果によれば材齢 91 日から 15 年までの強度増進は少なく、材齢 15 年コア強度の 91 日コア強度に 対する比は $0.93 \sim 1.22$ であった。強度レベル $50 \sim 60 \mathrm{~N} / \mathrm{mm}^{2}$ (水セメ ント比 $32 \sim 38 \%$ ）の実大柱試験体の材齢 10 年までのコア強度を調 べた研究 19 によれば、材齢10年コア強度の91日コア強度に対する比 は1.21 1.48であり、試験体によっては本研究と同程度の強度比が 報告されている。

本研究の柱No.4および柱No.5で長期的な強度増加が大きかった理 由として、(1)水セメント比が小さいため、材齢91日においても未 水和セメントが多く残っており、91日以降も水和反応が継続した こと、(2)部材厚の大きな柱試験体であるため、内部の水分が比較的 長期間保持されたこと等が考えられる。

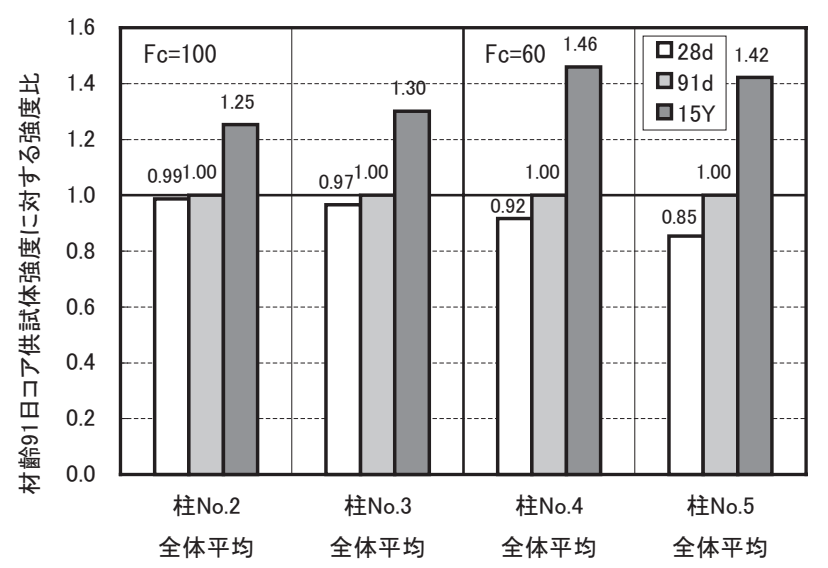

図6 材齢91日コア供試体強度に対する強度比 
$\mathrm{Fc} 100 \mathrm{~N} / \mathrm{mm}^{2}$ 級の柱No.2および柱No.3では、材齢28日から91日ま での強度増進は小さいが、91日から15年までの強度増進は大きい。 材齢 91 日から 15 年までの強度増加は、柱No.2では $27.0 \mathrm{~N} / \mathrm{mm}^{2}$ 、柱 No.3では $31.7 \mathrm{~N} / \mathrm{mm}^{2}$ であった。また、材齢 15 年コア強度の 91 日コア 強度に対寸る比は、柱No.2では1.25、柱No.3では1.30であった。 $\mathrm{Fc} 100 \mathrm{~N} / \mathrm{mm}^{2}$ を超える高強度コンクリートでは、材齢28日から 91 日 までの強度増進が少ないことは陣内らの研究 ${ }^{20}$ においても報告され ている。しかし、この強度レベルのコンクリートはまだ歴史が浅い ため、材齢 1 年以降の長期的な強度性状については明らかにされてい ない状況にあった。本研究の柱No.2および柱No.3で長期的な強度増 加が大きかった理由として、柱No.4および柱No.5 と同様に水セメ ント比が小さいため、材齢91日においても未水和セメントが多く 残っており、この未水和セメント部分が長期にわたって水和反応し たことが考えられる。

材齢 15 年コア強度の 91 日コア強度に対する比は、柱No.2および 柱No.3の方が柱No.4および柱No.5よりも小さな值となった。すな わち、 $140 \mathrm{~N} / \mathrm{mm}^{2}$ 付近で強度増加が緩慢になっている傾向が伺え る。渡邊らの研究 ${ }^{21}$ では、 $100 \mathrm{~N} / \mathrm{mm}^{2}$ を超える強度レベルのコン クリートにおいては粗骨材の強度がコンクリート強度に大きく影 響することが報告されている。本研究で用いた粗骨材については $140 \mathrm{~N} / \mathrm{mm}^{2}$ 付近よりコンクリート強度に及ぼす影響が顕在化したこ とも推測される。

柱No.2および柱No.3において、打込み方法の違いによる材齢 15 年コア強度の明確な違いは認められなかった。また、柱No.4およ び柱No.5において、型枠種類の違いによる材齢 15 年コア強度の明 確な違いは認められなかった。なお、材齢28日および91日におい ても、打込み方法、型枠種類の違いに起因したコア強度の差異は認 められなかった ${ }^{22}$ 。

\section{4 実大柱部材の材齢 15 年における中性化深さ}

表 6 に材齢 15 年における中性化深さ試験結果を示す。柱No.3およ び柱No.5に共通して、中性化深さは $0 \mathrm{~mm}$ であった。また、写真2に フェノールフタレイン $1 \%$ 溶液噴霧後の試験体を示寸。フェノールフ タレイン $1 \%$ 溶液を噴霧した試験体割裂面の寸べてが赤紫色に着色 している。和泉ら ${ }^{23}$ は本研究で対象としている柱試験体と同じコン クリートを用いて促進中性化試験（二酸化炭素濃度 $5 \%$ 、促進中性 化期間13週間）を実施している。その結果、材齢 1 日に脱型し、 材齢7日まで封かん養生したFc60のコンクリート試験体では中性化 深さが $2.8 \mathrm{~mm}$ 、同じく Fc100-Bのコンクリート試験体では中性化深 さが $0.7 \mathrm{~mm}$ であった。

実際の建築物から採取したコア供試体の中性化を調査した玉井 らの研究 ${ }^{24)}$ ではコア強度が $50 \mathrm{~N} / \mathrm{mm}^{2}$ を超えるコンクリートでは中性 化速度係数が $1 \mathrm{~mm} / \sqrt{ }$ year以下となり、中性化があまり進行しない ことが報告されている。また、屋外暴露した試験体の中性化に関 寸る既往の研究報告からデータを抽出・整理した長谷川らの研究 ${ }^{25}$ では、標準養生 28 日強度が $60 \mathrm{~N} / \mathrm{mm}^{2}$ 以上になると中性化速度係数が

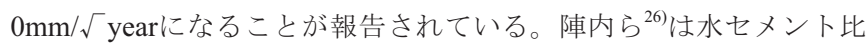
$21.4 \sim 71.4 \%$ の範囲のコンクリートを用いて促進中性化試験（二酸 化炭素濃度 5\%) を行っており、促進中性化期間26週間において水 セメント比 $40 \%$ 以下のコンクリートは中性化しなかったことを報 告している。
表6 中性化深さ試験結果（材齢15年）

\begin{tabular}{c|c}
\hline 試験体 & 中性化深さ $(\mathrm{mm})$ \\
\hline 柱No. 3 & 0 \\
\hline 柱No. 5 & 0 \\
\hline
\end{tabular}

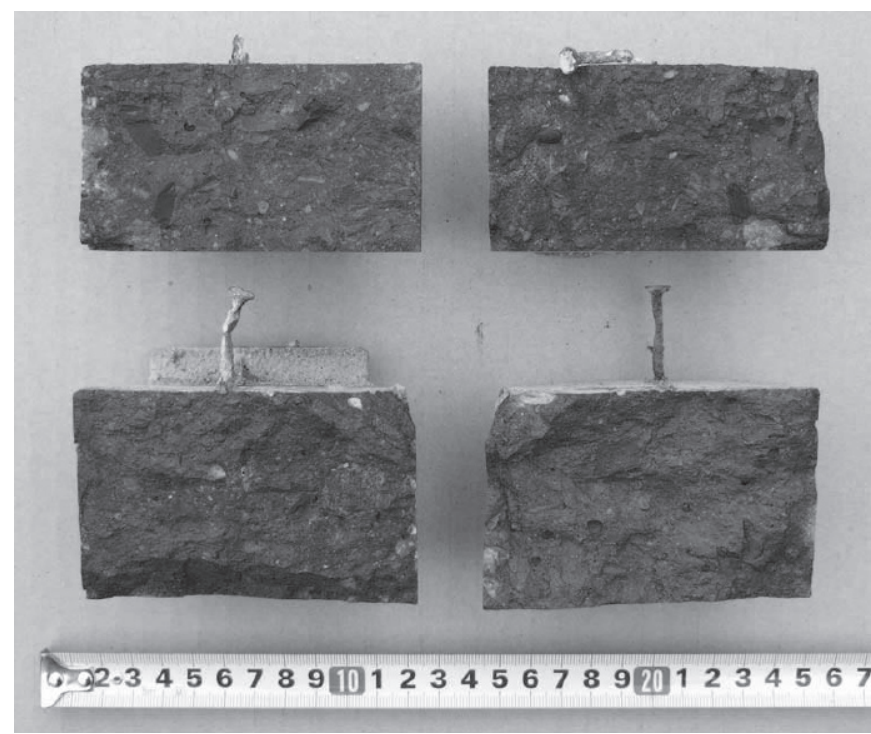

写真2 フェノールフタレイン $1 \%$ 溶液噴霧後の試験体 (上段の2つはNo.3，下段の2つはNo.5）

本研究で対象とした実際の強度が $70 \mathrm{~N} / \mathrm{mm}^{2}$ を超える高強度コンク リート（水セメント比 $27 \%$ 以下）については、一般大気中で材齢 15 年が経過しても中性化していないことが明らかとなり、既往の 研究報告からも予想される結果が得られた。

\section{5 実大柱部材から採取した試料のX線回折分析}

本研究では、材齢 15 年の柱試験体より採取したコンクリート小 片をもとに試料を作製し、2 $\theta=5 \sim 70(\mathrm{deg})$ の範囲のX線回折分析を 行ったが、特徴的な傾向が認められた $\theta=15 \sim 23(\mathrm{deg})$ の範囲および $2 \theta=27 \sim 35(\mathrm{deg})$ の範囲の分析結果を取り上げ、それぞれ図7、図8に 示寸。なお、X線回折分析では試料ホルダへの粉末試料の詰め具合 （圧力）のわずかな違いにより測定結果であるピーク強度に差異が 生じる ${ }^{27,}{ }^{28)}$ 。このため、内部標準物質として加えた酸化マグネシウ ムのピーク強度 $\mathrm{I}(\mathrm{MgO})$ を基準としたピーク強度比 $\mathrm{I} / \mathrm{I}(\mathrm{MgO})$ をそれ ぞれの試料について計算し、図7および図 8 における縦軸の変数と した。

図7において、2 $\theta=20.84(\mathrm{deg})$ に認められるピークは、コンクリー ト中の細骨材に含まれている $\mathrm{SiO}_{2}$ 成分によるものである。柱No.3で は中央部、隅角部および表面部の各試料間でピーク強度比が異なる ことから、細骨材の含有率が若干異なることがわかる。一方、柱 No.5ではそれぞれの試料についてピーク強度比がほぼ同じである ことから、細骨材の含有率に大差がないことがわかる。なお、シリ カフュームにも $\mathrm{SiO}_{2}$ 成分が含まれているが、非晶質であるため、X線 回折分析におけるピークとして検出されることはない。

柱No.5では2 $\theta=18.00(\mathrm{deg})$ に $\mathrm{Ca}(\mathrm{OH}) 2$ のピークが認められる。中 央部、隅角部に比べて表面部の方が $\mathrm{Ca}(\mathrm{OH})_{2}$ の量が少ないことがわ かる。一方、柱No.3では $\mathrm{Ca}(\mathrm{OH}) 2$ のピークは認められない。これは 柱No.3のコンクリートに使用されているシリカフュームがポゾラ 


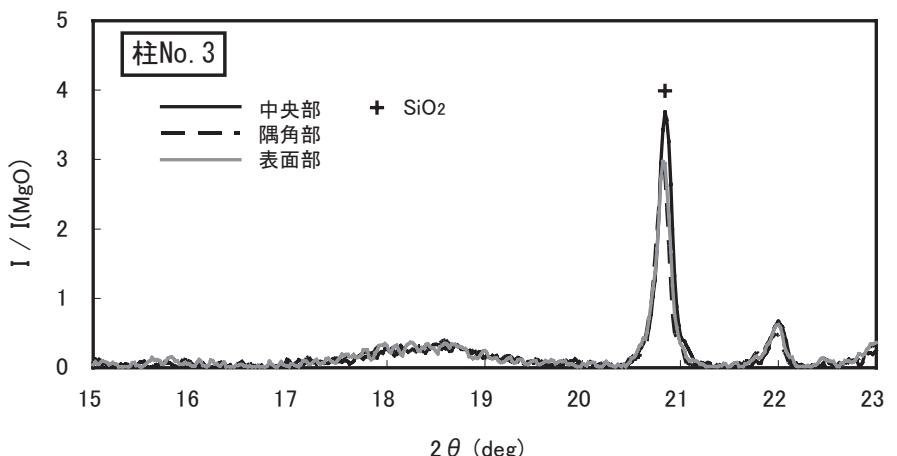

図7 X線回折分析結果

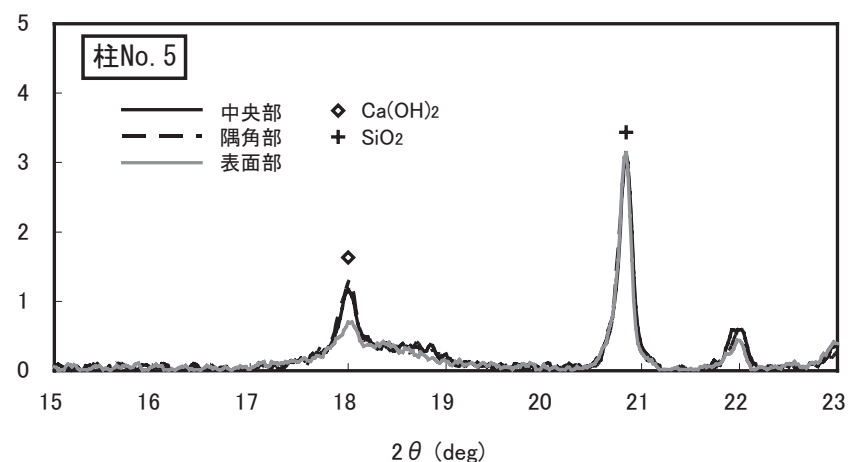

$(2 \theta=15 \sim 23 \mathrm{deg})$

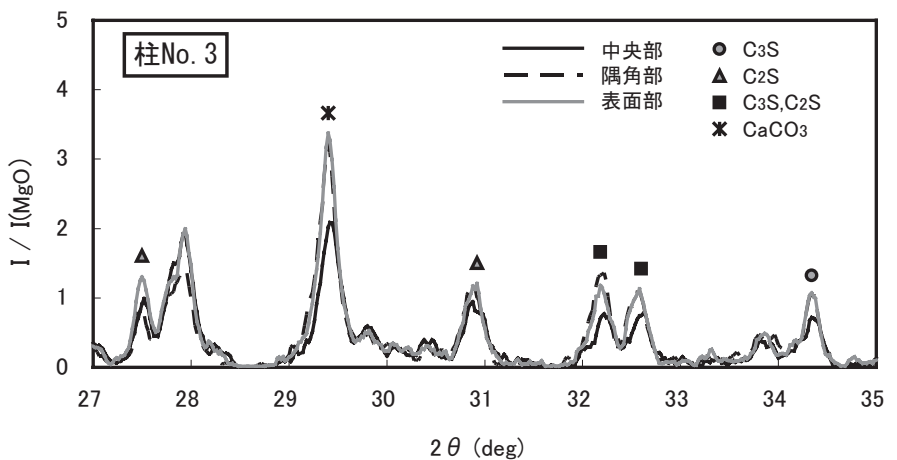

図8 X線回折分析結果

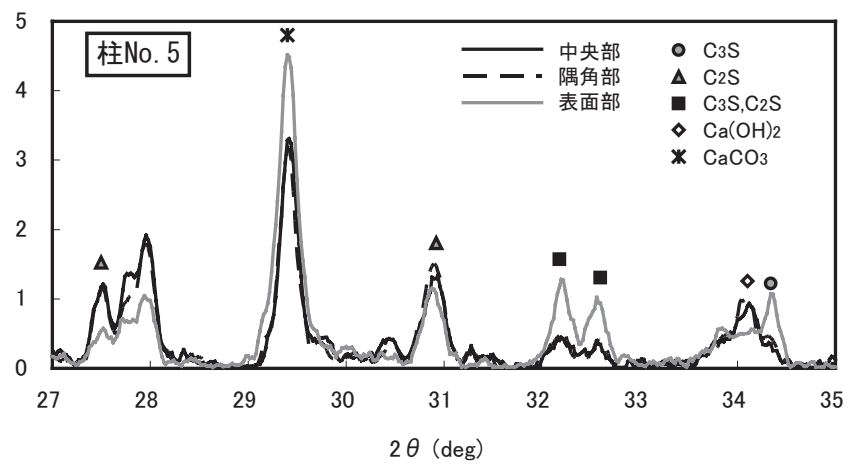

$(2 \theta=27 \sim 35 \operatorname{deg})$
ン反応する際に $\mathrm{Ca}(\mathrm{OH})_{2}$ を消費したためと考えられる。

図8では、柱No.3と柱No.5に共通して、2 $\theta=29.40(\mathrm{deg})$ に $\mathrm{CaCO}_{3}$ の ピークが認められる。本研究で用いた細骨材および粗骨材のX線回 折分析を別途行っており、細骨材および粗骨材には $\mathrm{CaCO}_{3}$ が含まれ ていないことを確認している。このため、図8で認められた $\mathrm{CaCO}_{3}$ は、 $\mathrm{Ca}(\mathrm{OH})_{2}$ が $\mathrm{CO}_{2}$ と反応することによって生成されたものと考え られる。図7に示された結果を加味すると、柱No.5では表面部の方 が中央部や隅角部に比べて $\mathrm{Ca}(\mathrm{OH})_{2}$ の量が少なく、 $\mathrm{CaCO}_{3}$ の量が多 いことがわかる。すなわち、外気に近いコンクリート表面部から中 性化が進行していることがわかる。一方、柱No.3においても表面 部で $\mathrm{CaCO}_{3}$ の量が多いが、柱No.3では各試料間で細骨材含有率の差 異が認められたため、定量的な比較を正確に行うことは困難であっ た。

フェノールフタレインの変色域は $\mathrm{pH} 8.2 \sim 10.0$ の範囲であり、 $\mathrm{pH}<8.2$ の酸性側では無色、 $\mathrm{pH}>10.0$ の塩基性側では赤紫色を示 寸 ${ }^{29), 30)}$ 。3.4の結果を加味すると、本研究で対象とした実際の強度 が $70 \mathrm{~N} / \mathrm{mm}^{2}$ を超える高強度コンクリートでは、材齢 15 年において フェノールフタレイン $1 \%$ 溶液を噴霧する方法により中性化と判定 されるまでには至っていないが、コンクリート中の $\mathrm{Ca}(\mathrm{OH}) 2$ が空気 中の $\mathrm{CO}_{2}$ と反応し、 $\mathrm{CaCO}_{3}$ に変化する過程がわずかながら進行して いることがわかる。

また、図8では柱No.3 と柱No.5に共通して、未反応の $\mathrm{C}_{3} \mathrm{~S}$ およ び $\mathrm{C}_{2} \mathrm{~S}$ のピークならびに両者のピークが重なって現れている部分 (図8中で口点で表した角度のピーク) が認められる。3.3では、材 齢91日から 15 年までのコア強度の増加が大きかった理由として、 水セメント比が小さいため材齢91日においても未水和セメントが 多く残っていたことを取り上げた。X線回折分析により、材齢15年
においても未水和セメントが残存していることが明らかになった。 材齢 15 年以降も残存している $\mathrm{C}_{3} \mathrm{~S}$ および $\mathrm{C}_{2} \mathrm{~S}$ が水和反応し、コンク リート強度が増進することも考えられる。

4. まとめ

高強度コンクリートの長期性状を明らかにすることを目的とし て、総プロ New RCで作製された設計基準強度 $100 \mathrm{~N} / \mathrm{mm}^{2}$ 級および $60 \mathrm{~N} / \mathrm{mm}^{2}$ 級のコンクリートを用いた実大の柱試験体を対象に材齢 15 年におけるコア強度および中性化深さを調查し、以下の結果を得 た。

1) 柱試験体より鉛直方向に高さ $2900 \mathrm{~mm}$ のコアを採取し、所定の 高さ位置で切断・研磨した供試体の圧縮強度試験を行ったとこ ろ、材齢 15 年ではす心゙てのコア供試体が設計基準強度を満足して いた。

2）コア供試体の採取高さと強度の関係については、Fc60N $/ \mathrm{mm}^{2}$ 級 の柱試験体の中央部において、材齢 15 年では上部よりも下部の方 がコア強度が高い傾向が認められた。Fc100N/mm 級の柱試験体 では、コア供試体の採取高さと強度には明確な関係が認められな かった。

3) $F c 60 \mathrm{~N} / \mathrm{mm}^{2}$ 級、Fc100N/mm 2 級の柱試験体に共通して、材齢 15 年 では中央部の方が隅角部よりも高いコア強度を示した。

4）材齢 91 日以降も継続して強度が増進し、材齢 15 年コア強度の材齢 91日コア強度に対する比は、Fc60 N/ $\mathrm{mm}^{2}$ 級の柱試験体では1.42〜 1.46、 Fc100N/mm²級の柱試験体では1.25～1.30であった。

5) $\mathrm{Fc} 60 \mathrm{~N} / \mathrm{mm}^{2}$ 級、 $\mathrm{Fc} 100 \mathrm{~N} / \mathrm{mm}^{2}$ 級の柱試験体に共通して、材齢 15 年 における中性化深さは0mmであった。

6） X線回折分析を行ったところ、材齢 15 年ではコンクリート中の 
$\mathrm{Ca}(\mathrm{OH})_{2}$ が空気中の $\mathrm{CO}_{2}$ と反応して $\mathrm{CaCO}_{3}$ に変化していることが 明らかになった。また、外気に近い表面部の方が中央部よりも $\mathrm{CaCO}_{3}$ の量が多かった。フェノールフタレイン $1 \%$ 溶液を噴霧す る方法により中性化と判定されるまでには至っていないが、表 面部から中性化が進行している傾向が伺えた。

7） $\mathrm{Fc} 60 \mathrm{~N} / \mathrm{mm}^{2}$ 級、Fc100N/mm²級の柱試験体に共通して、材齢 15 年 においても未水和の $\mathrm{C}_{3} \mathrm{~S} お よ ひ ゙ \mathrm{C}_{2} \mathrm{~S}$ が残存していた。

\section{謝辞}

本研究で調查対象とした実大の柱試験体は、建設省総合技術開発 プロジェクト「鉄筋コンクリート造建築物の超軽量・超高層化技術 の開発（昭和63年度〜平成4年度）」の一環として作製されたもので ある。当時関係された諸氏のおかげで今般貴重なデータを入手する ことができた。ここに記して、深く謝意を表す。なお、材龃15年の 調查・分析については、第一著者が平成20年3月まで在籍していた独 立行政法人建築研究所の研究課題の一部として実施したことを付記 する。

\section{参考文献}

1) 建設省総合技術開発プロジェクト「鉄筋コンクリート造建築物の超軽量・ 超高層化技術の開発」平成 4 年度高強度コンクリート分科会報告書, (財) 国土開発技術研究センター, 1993.3

2) 桝田佳寛, 上村克郎, 友沢史紀, 清水昭之, 阿部道彦ほか：高強度鉄筋コ ンクリートを用いた施工実験のまとめと施工標準への反映（New RC 実大 施工実験 その 31), 日本建築学会大会学術講演梗概集 A-1, pp.359-360, 1992.8

3) 岡本公夫, 上村克郎, 友沢史紀, 清水昭之, 桝田佳寛ほか: 高強度鉄筋コ ンクリートを用いた施工実験の概要（New RC 実大施工実験 その 1), 日 本建築学会大会学術講演梗概集 A-1, pp.299-300, 1992.8

4) 佐藤孝一, 栘田佳寛, 平賀友晃, 上西隆ほか : 柱形試験体による高強度コ ンクリートの施工性の検討（New RC 実大施工実験 その 5), 日本建築学 会大会学術講演梗概集 A-1, pp.307-308, 1992.8

5) 下川浩児, 栘田佳寛, 田中恭一, 橋爪進ほか : 高強度コンクリートの調合 に関する実験（New RC 実大施工実験 その 2), 日本建築学会大会学術講 演梗概集 A-1，pp.301-302，1992.8

6) 田中恭一，栘田佳寛，阿部道彦，平賀友晃ほか：実機プラントにおける高 強度コンクリートの調合実験（New RC 実大施工実験 その 3), 日本建築 学会大会学術講演梗概集 A-1, pp.303-304, 1992.8

7) 山浦一郎, 岡村一臣, 岡本公夫, 下川浩児ほか : 高強度コンクリートを用 いた柱形試験体のコア強度性状（New RC 実大施工実験 その 22），日本 建築学会大会学術講演梗概集 A-1, pp.341-342, 1992.8

8) 毛見虎雄, 平賀友晃ほか: 比較的マッシブなコンクリート構造物の強度 分布 (その $1 \sim 2$ ), 日本建築学会大会学術講演梗概集 A-1, pp.227-230, 1978.9

9) Yoshio Kasai and Isamu Matsui : Studies on concrete strength of structure in Japan, RILEM symposium control of concrete structures, June 1979, Stockholm Sweden

10) 梅本宗宏, 篠崎 徹, 板谷俊郎, 平賀友晃 : 低発熱ポルトランドセメント を用いた高強度コンクリートの柱構造体強度の検討, コンクリート工学年 次論文集, Vol.18, No. 1, pp.309-314, 1996

11) 下川裕一, 須藤栄治, 清水昭之, 寺田謙一ほか：高強度コンクリートの締 固めと充填性の検討（New RC 実大施工実験 その 18), 日本建築学会大 会学術講演梗概集 A-1, pp.333-334, 1992.8

12) 仕入豊和, 地濃茂雄 : コンクリートの初期強度に及ぼす温度条件 (20 $90^{\circ} \mathrm{C}$ ) の影響, 日本建築学会論文報告集, 第 320 号, pp.1-11, 1982.10

13) 地濃茂雄, 仕入豊和: コンクリートの強度発現性状に及ぼす温度履歴条 件 $\left(20 \sim 90^{\circ} \mathrm{C}\right)$ の影響, 日本建築学会論文報告集, 第 337 号, pp.8-14, 1984.3

14) 杉山 央，桝田佳寛 : 初期高温履歴を受けたコンクリートの長期強度発現 性, 日本建築学会構造系論文集, 第 515 号, pp.23-30, 1999.1

15) 杉山 央：高強度マスコンクリートの温度履歴特性と強度発現性，コンク リート工学, Vol.38, No.7, pp.3-9, 2000.7
16) 桝田佳寛, 佐藤幸惠, 友澤史紀 : 高強度コンクリートの構造体中での強 度発現性と調合強度, 日本建築学会構造系論文集，第 537 号，pp.13-20， 2000.11

17) 岡村一臣，山浦一郎，塩見伊津夫，須藤栄治ほか：高強度コンクリートを 用いた柱形試験体の内部温度とコア強度の関係（New RC 実大施工実験 その 23), 日本建築学会大会学術講演梗概集 A-1, pp.343-344, 1992.8

18) 嵩 英雄, 玉井孝幸, 阿部道彦, 友澤史紀ほか： 25 年経過した実大 RC 壁 体における普通および流動化コンクリートの構造体強度に関する研究, 日 本建築学会構造系論文集, 第 612 号, pp.9-15, 2007.2

19) 安田正雪, 栘田佳寬, 高橋宏治ほか：高強度コンクリートを用いた実大柱 の長期強度試験結果（材齢約 10 年），日本建築学会大会学術講演梗概集 A-1, pp.361-362, 2005.9

20) 陣内 浩, 黒岩秀介, 早川光敬, 並木 哲ほか：設計基準強度 $150 \mathrm{~N} / \mathrm{mm}^{2}$ クラスの高強度コンクリートによる実大 RC 柱の施工性と構造体強度発現 性状の検討, 日本建築学会技術報告集, 第 17 号, pp.1-6, 2003.6

21) 渡邊悟士, 黒岩秀介, 陣内 浩, 並木 哲: 高強度コンクリートの圧縮強 度に影響を及ぼす粗骨材物性に関する研究, 日本建築学会構造系論文集, 第 588 号, pp.21-27, 2005.2

22) 松本雅之, 中根 淳, 一瀬賢一, 岡本公夫 : 高強度コンクリートの強度発 現に及ぼす各種施工要因の検討（New RC 実大施工実験 その 26), 日本 建築学会大会学術講演梗概集 A-1, pp.349-350, 1992.8

23) 和泉意登志, 阿部道彦：せき板存置期間と初期養生が高強度コンクリート の品質に及ぼす影響（New RC 実大施工実験 その 17），日本建築学会大 会学術講演梗概集 A-1, pp.331-332, 1992.8

24) 玉井孝幸，林 静雄，桝田佳寛，兼松 学ほか：構造体コンクリートの 圧縮強度と中性化の実態調査, 日本建築学会大会学術講演梗概集 A-1, pp.459-460, 2006.9

25) 長谷川拓哉, 千歩 修: 文献調査に基づく屋外の中性化進行予測, コンク リート工学年次論文集，Vol.28，No.1，pp.665-670， 2006

26) 陣内 浩, 並木 哲, 黒岩秀介, 渡邊悟士 : 高強度コンクリートの長期的 な長さ変化と中性化に関する研究, 日本建築学会構造系論文集, 第 594 号, pp.9-15, 2005.8

27) 加藤誠軌：X線回折分析, 内田老確圃, 1994

28) 桜井敏雄 : X線結晶解析の手引き, 裳華房, 1997

29) 理化学辞典, 岩波書店, pp.1155, 1998

30) 理工学辞典, 日刊工業新聞社, pp. 1260,1996

(2008年 4 月 9 日原稿受理，2008年 6 月 4 日採用決定） 